\title{
Efect of Ethanolic Leaf Extract of Sauraunia vulcani Korth on Lymphocyte and IL-In Immunized Rats
}

\author{
Erlintan Sinaga ${ }^{1}$, Syafruddin Ilyas ${ }^{2 *}$, Salomo Hutahaean ${ }^{2}$, Panal Sitorus ${ }^{3}$ \\ ${ }^{1}$ Department of Biology, Faculty og Mathematics and Natural Sciences, Medan State University, \\ Medan, Indonesia, \\ ${ }^{2}$ Department of Biology, Faculty of Mathematics and Natural Sciences, Universitas Sumatera Utara, \\ Medan, Indonesia, \\ ${ }^{3}$ Department of Pharmacy, Faculty of Pharmacy, Universitas Sumatera Utara, Medan, Indonesia \\ ${ }^{*}$ Corresponding author: \\ Email: syafruddin6@usu.ac.id
}

\begin{abstract}
.
Ethanolic leaf extract of Saurauia vulcani Korthor pirdot in Indonesia was evaluated to improve the number of erythrocytes in laboratory rats after being immunized with sheep red blood cells (SRBC). This study was conducted in an experimental manner using a non-factorial Completely Randomized Design (CRD) with four treatments and six replications. The tested animals were 24 rats (Rattus norvegicus) maintained in the laboratory. The experimental designs were designated as follows: Goas a control group treatedwith regular animal feed, $G_{1}$ was treated with $0.1 \mathrm{mLSRBC}, \mathrm{G}_{2}$ was treated with $500 \mathrm{mg}$ ethanolic leaf extract of Saurauia

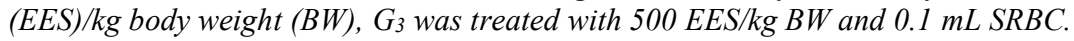
The immunological effect was monitored by analyzing the level of interleukin-2 (IL2) using ELISA, lymphocytes using ABX Microx 60, and liver histopathology. The results showed that lymphocyte levels was increased in $G_{2}$ and $G_{3}$ but not significant to $G_{0}$. The IL-2 level in $G_{1}$ was recorded the highest among groups due to the treatment using SRBC. The percentage of necrotic cells in GIwas $5.8 \%$, followed by $G_{3}$ with $2.3 \%$. The morphologies of liver histology were normal, parenchymatous and hydropic degenerations, and necrosis. The phytochemical constituents in ethanolic leaf extract of $S$. vulcanipossessed an immunological effect through the increased lymphocytes, reduction of $I L-2$, and protection through normal liver histopathology in rats.
\end{abstract}

Keywords: Ethanolic extract, Saurauia vulcani Korth, lymphocytes

\section{INTRODUCTION}

The immune system is known to be involved in the etiology of various physiological disorders, i.e infection, cancer, and autoimmune. Thus, modulation of the immune system plays an important role as efforts to prevent and treat various diseases. Researchers around the world are also conducting biomedical studies to identify and explore either natural or synthetic compounds which can stimulate or even modulate the activity of the immune system, which are called immunostimulants. Immunostimulants can be used in situations where the immune system is compromised or as a preventive method to the onset of disease. 
People often use immunostimulants in a healthy state to enhance their immunity for not being easily susceptible to some diseases and in a state of illness to speed up recovery. Natural compounds commonly utilized by people to stimulate the immune system i.e, Carica papaya,Centella asiatica, Curcuma domestica, Phaleria macrocarpa, Phyllanthus urinaria, Zingiber officinale, (Sundaryono, 2011) and Saurauia vulcani Korth or pirdot in Indonesia (Sitorus, 2015).

Saurauia vulcani (Actinidiaceae) is a medicinal plant species with potential bioactive phytocompounds which has not been widely used or known to the public. The utilization of this species is still limited to the Toba Batak community, an indigenous tribe from North Sumatra, to treat hyperlipidemia, diabetes, cancer, and wound healing. Based on the local interviews in North Tapanuli, it is believed that $S$. vulcanimay also improve the immunity and can prevent various diseases. Majority of studies regarding isolation of plant extracts used ethanol $(\mathrm{EtOH})$ as a universal solvent due to its polarity. Ethanol is widely used to obtain more of the bioactive phytocompounds (Harborne, 1987). Ethanol is also characterized by having a high polarity for a better extraction, followed with other features i.e low boiling point, and non-toxic for biological application.

Evaluation of the immunostimulatory activity of drugs or medicinal plants, can be measured by interpreting several parameters such as hematological profile and interleukin-2 (IL-2) level. In this study, the immunostimulatory activity of $S$. vulcani leaves in rats was observed through lymphocyte levels. According to Sitorus (2015), $S$. vulcani contained flavonoids, saponins, steroids, tannins and glycosides. Other study by Rajput et al. (2007), flavonoids and saponins had the ability to modulate specific immune responses to increase cytokine production as a mediator of the immune response which can also induce a humoral response thereby increasing antibody production (Francis et al., 2002; Nair et al., 2002).

Based on the previous insights, $S$. vulcani was tested for its immunostimulatory activity by measuring the level of lymphocytes and IL-2 using ELISA method, and observing the physical condition of liver through histopathological analysis.

\section{METHODS}

\subsection{Location and time of the research}

This research was conducted from April 2016 to April 2019. Laboratoryrats(Rattus novergicus) weremaintained in cages at the Laboratory of Applied Pharmacology, Faculty of Medicine, Universitas Padjadjaran, Bandung. The ethanolic extraction of $S$. vulcani leaf was conducted at the Laboratory of Pharmacy,Institut Teknologi Bandung, Bandung. Measurement of interleukin level (IL-2) was conducted at the Laboratory of Genetics and Biomolecular, Faculty of Medicine, Universitas Padjadjaran, Bandung.

\subsection{Materials}

Materials used in this study consisted of rat cages made of plastic with a size of $40 \times 30 \times 20 \mathrm{~cm}$, equipped with wire netting at the top as a cage cover. The number of cages used was sixteen, equipped with a site for feeding and drinking for reared rats. Vacuum tube and syringes were used to collect blood samples as well as to inject sheep red blood cells (SRBC). A blender was used to homogenize the size of $S$. vulcani simplicia prior extraction. A rotaryevaporator was used to concentrate the crude extract 
followed with a drying process with a water bath to reduce the remaining volume of $\mathrm{EtOH}$ in the extract.

Measurement of IL-2 levels followed the ELISA kit procedure. Measurement of hematological profile was based on the absorbance using a spectrophotometer with Micros ABX 60 specifications. Analysis of antibody titers was performed on a 96-well $\mathrm{V}$ microplate followed with ELISA reading. Plant sample or $S$. vulcani used in this study was collected from the forest in North Tapanuli. Ethanolic extraction was conducted using a 96\% EtOH solvent. Twenty-four laboratory rats aged two months withbody weight of 150-200 gr, wereused in this experimental study.

Preparation of sheep red blooc cells (SRBC) as antigen consisted of phosphate buffer saline (PBS) and alsever S solution. For immunoglobulin analysis, the Rat IgG and IL-2 Elisa Kit (Cat no. E111-100), Rat IgG Elisa Kit (Sigma), ELISA Coating Buffer (Cat No. E107), and a wash solution buffer (Cat No. 106) as rinsing, were used for ELISA reading. Hematological profiling used EDTA solution as an anti-coagulant, fixed with Xylol and Eosin dyes.

\subsection{Experimental design}

The design in this study was listed in Table 1. The duration of treatment was maintained until 30 days for $G_{0}, G_{1}$, and $G_{2}$, while the administration of SRBC was given during the $8^{\text {th }}$ and $15^{\text {th }}$ day of treatment for $\mathrm{G}_{3}$.

Table 1. Experimental group description using laboratory rats (Rattus novergicus)

\begin{tabular}{|c|c|}
\hline Treatment & Group \\
\hline Animal feed + Na-CMC & $\mathrm{G}_{0}$ \\
\hline Animal feed + SRBC & $\mathrm{G}_{1}$ \\
\hline Animal feed + EES & $\mathrm{G}_{2}$ \\
\hline Animal feed + EES + SRBC & $\mathrm{G}_{3}$ \\
\hline
\end{tabular}

Note: $\mathrm{Na}-\mathrm{CMC}=$ Natrium - Carboxy Methyl Cellulose, $\mathrm{SRBC}=$ Sheep red blood cells,

$\mathrm{EES}=$ Ethanolic leaf extract of $S$. vulcani

2.4 Preparation of $I L-2$ reagents

Preparation of IL-2 reagents followed the technical procedure by Rat IgG kit (Ebioscience Cat. No. 88-50490-22 dan 88-5054-22). Coating buffer was prepared by diluting $10 \times$ of phosphate buffer saline (PBS) with double distilled water. Blocking buffer was prepared from a $20 \times$ dilution of buffer A with double distilled water. Capture antibodies was diluted a $250 \times$ dilution from coating buffer.

2.5 IL-2 analysis

The stepwise procedure of IL-2 analysis was described as follows: Plate was coated with corning costar 9018 ELISA with $100 \mu \mathrm{L} /$ well of diluted capture antibody and incubated at $4^{\circ} \mathrm{C}$ for $24 \mathrm{~h}$. Blocking buffer and wells were washed twice with 400 $\mu \mathrm{L} /$ well per wash buffer solution. The plate was immersed for $1 \mathrm{~min}$ for each washing followed with drying to remove the remaining buffer solution. Plate was filled with $250 \mu \mathrm{L}$ blocking buffer and incubated at $37^{\circ} \mathrm{C}$ for $2 \mathrm{hr}$, followed with washing. A twofold serial dilution of standard in buffer A was developed to construct a standard curve from an initial concentration of $100 \mathrm{ng} / \mathrm{mL}$. The standard solution was placed $100 \mu \mathrm{L}$ into each well with five replications. One-hundred $\mu \mathrm{L}$ of buffer A was filled into initial well, and diluted by removing $75 \mu \mathrm{L}$ into $25 \mu \mathrm{L}$ of samples until $10^{6}$ fold dilution. Plate was covered and incubated at $37^{\circ} \mathrm{C}$ for $2 \mathrm{hr}$. Wells were washed four times 
followed by addition of $100 \mu \mathrm{L}$ of substrate solution into each well and incubated for $15 \mathrm{~min}$. The absorbance reading using ELISA was performed at $450 \mathrm{~nm}$.

\subsection{Data analysis}

Parametric data in groups of more than two treatments were tabulated, then analyzed using ANOVA at an error level of 5\% through a bootstrapping process. If the results are significant $(\mathrm{p}<0.05)$, then proceed with the a post-goc test or Duncan's test, usinga statistical program (SPSS ver. 23). In addition, the non-parametric data were analyzed with the Kruskal Wallis test and if $\mathrm{p}<0.05$, a post-hoc or Mann-Whitney test was performed to compare each treatment group.

\section{RESULT AND DISCUSSION}

\subsection{Location and time of the research}

This research was conducted from April 2016 to April 2019. Laboratoryrats(Rattus novergicus) weremaintained in cages at the Laboratory of Applied Pharmacology, Faculty of Medicine, Universitas Padjadjaran, Bandung. The ethanolic extraction of $S$. vulcani leaf was conducted at the Laboratory of Pharmacy,Institut Teknologi Bandung, Bandung. Measurement of interleukin level (IL-2) was conducted at the Laboratory of Genetics and Biomolecular, Faculty of Medicine, Universitas Padjadjaran, Bandung.

\subsection{Materials}

Materials used in this study consisted of rat cages made of plastic with a size of $40 \times 30 \times 20 \mathrm{~cm}$, equipped with wire netting at the top as a cage cover. The number of cages used was sixteen, equipped with a site for feeding and drinking for reared rats. Vacuum tube and syringes were used to collect blood samples as well as to inject sheep red blood cells (SRBC). A blender was used to homogenize the size of S. vulcani simplicia prior extraction. A rotaryevaporator was used to concentrate the crude extract followed with a drying process with a water bath to reduce the remaining volume of $\mathrm{EtOH}$ in the extract.

Measurement of IL-2 levels followed the ELISA kit procedure. Measurement of hematological profile was based on the absorbance using a spectrophotometer with Micros ABX 60 specifications. Analysis of antibody titers was performed on a 96-well $\mathrm{V}$ microplate followed with ELISA reading. Plant sample or S. vulcani used in this study was collected from the forest in North Tapanuli. Ethanolic extraction was conducted using a 96\% EtOH solvent. Twenty-four laboratory rats aged two months withbody weight of 150-200 gr, wereused in this experimental study.

Preparation of sheep red blooc cells (SRBC) as antigen consisted of phosphate buffer saline (PBS) and alsever S solution. For immunoglobulin analysis, the Rat IgG and IL-2 Elisa Kit (Cat no. E111-100), Rat IgG Elisa Kit (Sigma), ELISA Coating Buffer (Cat No. E107), and a wash solution buffer (Cat No. 106) as rinsing, were used for ELISA reading. Hematological profiling used EDTA solution as an anti-coagulant, fixed with Xylol and Eosin dyes.

\subsection{Experimental design}

The design in this study was listed in Table 1. The duration of treatment was maintained until 30 days for $G_{0}, G_{1}$, and $G_{2}$, while the administration of SRBC was given during the $8^{\text {th }}$ and $15^{\text {th }}$ day of treatment for $\mathrm{G}_{3}$. 
Table 1. Experimental group description using laboratory rats (Rattus novergicus)

\begin{tabular}{|c|c|}
\hline Treatment & Group \\
\hline Animal feed + Na-CMC & $\mathrm{G}_{0}$ \\
\hline Animal feed + SRBC & $\mathrm{G}_{1}$ \\
\hline Animal feed + EES & $\mathrm{G}_{2}$ \\
\hline Animal feed + EES + SRBC & $\mathrm{G}_{3}$ \\
\hline
\end{tabular}

Note: Na-CMC $=$ Natrium - Carboxy Methyl Cellulose, $\mathrm{SRBC}=$ Sheep red blood cells, EES = Ethanolic leaf extract of $S$. vulcani

\subsection{Preparation of IL-2 reagents}

Preparation of IL-2 reagents followed the technical procedure by Rat IgG kit (Ebioscience Cat. No. 88-50490-22 dan 88-5054-22). Coating buffer was prepared by diluting $10 \times$ of phosphate buffer saline (PBS) with double distilled water. Blocking buffer was prepared from a $20 \times$ dilution of buffer A with double distilled water. Capture antibodies was diluted a $250 \times$ dilution from coating buffer.

\subsection{IL-2 analysis}

The stepwise procedure of IL-2 analysis was described as follows: Plate was coated with corning costar 9018 ELISA with $100 \mu \mathrm{L} /$ well of diluted capture antibody and incubated at $4^{\circ} \mathrm{C}$ for $24 \mathrm{~h}$. Blocking buffer and wells were washed twice with 400 $\mu \mathrm{L} /$ well per wash buffer solution. The plate was immersed for 1 min for each washing followed with drying to remove the remaining buffer solution. Plate was filled with $250 \mu \mathrm{L}$ blocking buffer and incubated at $37^{\circ} \mathrm{C}$ for $2 \mathrm{hr}$, followed with washing. A twofold serial dilution of standard in buffer A was developed to construct a standard curve from an initial concentration of $100 \mathrm{ng} / \mathrm{mL}$. The standard solution was placed $100 \mu \mathrm{L}$ into each well with five replications. One-hundred $\mu \mathrm{L}$ of buffer $\mathrm{A}$ was filled into initial well, and diluted by removing $75 \mu \mathrm{L}$ into $25 \mu \mathrm{L}$ of samples until $10^{6}$ fold dilution. Plate was covered and incubated at $37^{\circ} \mathrm{C}$ for $2 \mathrm{hr}$. Wells were washed four times followed by addition of $100 \mu \mathrm{L}$ of substrate solution into each well and incubated for $15 \mathrm{~min}$. The absorbance reading using ELISA was performed at $450 \mathrm{~nm}$.

\subsection{Data analysis}

Parametric data in groups of more than two treatments were tabulated, then analyzed using ANOVA at an error level of 5\% through a bootstrapping process. If the results are significant $(\mathrm{p}<0.05)$, then proceed with the a post-goc test or Duncan's test, usinga statistical program (SPSS ver. 23). In addition, the non-parametric data were analyzed with the Kruskal Wallis test and if $\mathrm{p}<0.05$, a post-hoc or Mann-Whitney test was performed to compare each treatment group.

\section{RESULT AND DISCUSSION}

\subsection{Identification of S. vulcani Korth.}

Based on the specimen authentication at Herbarium Bogoriense,Indonesian Institute of Sciences (LIPI), Bogor on July 11, 2016, pirdot was identified as Saurauia vulcani Korth. With referencenumber 1197/IPH.1.02/If.8/VII/2016. Based on the results, the species belongs to Actinidiaceae with following characteristics: the upper side of leaf is green while the lower is brown, the marginis serrated, the young leaves have the most hairs and decease following maturity, the leaves are thick and stiff, the 
cup-shaped flowers with five pistilles are located on the axilla of the leaves surrounded by the round and tapered oval-shaped bractea (Tumangger, et al. 1999).

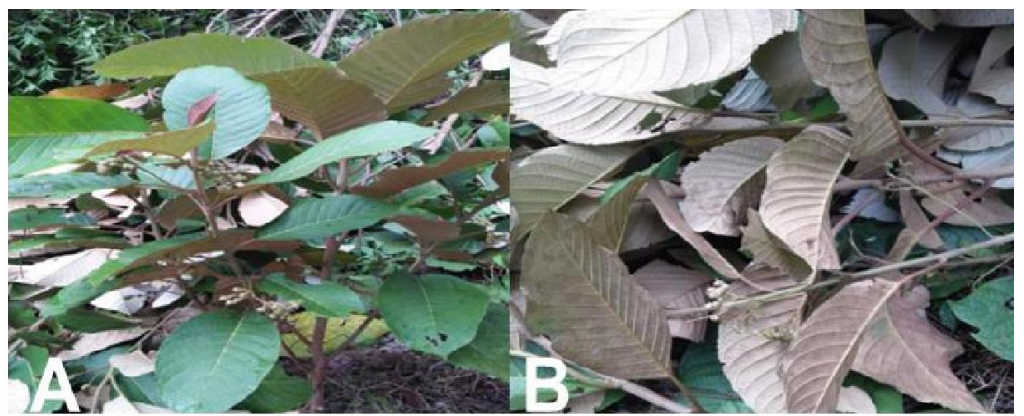

Fig 1. Upper (A) and lower (B) leaf of pirdot (Saurauia vulcani Korth.)

The complete systematics of $S$. vulcani Korth are as follows:

$\begin{array}{ll}\text { Kingdom } & \text { : Plantae } \\ \text { Division } & \text { : Magnoliophyta } \\ \text { Class } & \text { : Magnoliopsida } \\ \text { Order } & \text { : Theales } \\ \text { Family } & \text { : Actinidiaceae } \\ \text { Genus } & \text { : Saurauia } \\ \text { Species : Saurauia vulcani Korth. }\end{array}$

\subsection{Effect of ethanolic leaf extract of S. vulcani to lymphocytes profile}

Based on the statistical analysis, there was no significant difference in the percentage of lymphocyte among groups (ANOVA, $\mathrm{p}>0.05$ ). Furthermore, based on the Duncan test, $\mathrm{G}_{2}$ had the highest lymphocyte percentage $(78.40 \pm 4.02 \%)$ of all groups, followed by $\mathrm{G}_{3}(75.40 \pm 3.21 \%)$, and $\mathrm{G}_{0}(74.00 \pm 2.92 \%)$, while the lowest percentage from $\mathrm{G}_{1}$ $(69.16 \pm 4.96 \%)$. There was no significant difference between G0, G1, and G3 (Figure $2)$. From Figure 2, it can be seen that the administration of ethanolic leaf extract of $S$. vulcani or EES has an effect on the number of lymphocytes in which tend to increase from both $\mathrm{G}_{2}$ and $\mathrm{G}_{3}$ although not significantly different from control $\left(\mathrm{G}_{0}\right)$. Based on these results, the EES may be considered as immunostimulant to rats. This immunostimulatory activity is due to the presence of saponins, flavonoids and steroids which improve immunity function through stimulation of cell division and lymphocyte transformation (Govind, et al., 2012).

Abbas et al. (2004) stated that lymphocytes specifically recognize and respond to external antigens and subsequently act as cell-mediated and humoral mediators. Similar opinion by Galindo and Hosokawa (2004) which stated that lymphocytes are part of the cellular defense system, impacting on immunological memory. Lymphocytes are divided into two groups, namely $\mathrm{T}$ and $\mathrm{B}$ lymphocytes (Akrom and Siti, 2007). T lymphocytes play an important role in cellular immune response by responding directly to antigen through surface receptors and also activate $\mathrm{B}$ cell proliferation to produce antibodies. as well as macrophage activity in phagocytosis. The resulting specific antigen response will result in the large production of $\mathrm{B}$ lymphocytes and antibodies or plasma glycoproteins and can bind to antigens which stimulate the phagocytosis (Suhirman and Christina, 2006). 
The ethanolic leaf extract of Saurauia vulcani Korth. contains a bioactive compound from the flavonoid group, namely genistein (Sormin, 2017), which is thought to act as an immunostimulant through increased lymphocyte proliferation. These results are consistent with previous studies which reported the effect of medicinal plant extracts rich in polyphenolic compounds. Flavonoids act as protective compounds against damage caused by the reactive oxygen species (ROS) by increasing the level of antioxidant activities (Boligon et al. 2000; Hayder et al. 2004; Wilms et al. 2005).

The cellular mechanism of DNA protection by human lymphocytes against oxidative stress using quercetin (flavonol) has been described in the previous studies (Wilms et al. 2005; Duthie et al. 2007; Duthie et al. 2007; Min et al. 2009). Hydrogen peroxide is a reactive chemical compound which can elevate the production of hydroxyl radicals through Fenton reaction $\left(\mathrm{H}_{2} \mathrm{O}_{2}+\mathrm{Fe}^{2+} \rightarrow \mathrm{Fe}(\mathrm{III})+\mathbf{O H}^{-}+\mathbf{O H}\right)$. The free $-\mathrm{OH}$ species may bind to DNA causing disruption and interrupts with DNA stability leading to cellular reaction of carcinogenesis (Duthie et al. 2007; Min et al. 2009).The protective effect of flavonoids as antioxidants, including their activities to inhibit the xanthine oxidase, removing the superoxide anions and hydroxyl radicals, lies from the presence of multiple hydroxyle chains in the B-ring of flavonoid (Cotelle et al. 1996). Furthermore, Cao et al. (1997) explained that the hydroxyl configuration of B-ring is the significant factor to prevent ROS incidence by donating the hydrogen ions, hydroxyl electrons, peroxyl ( $\mathrm{ROO} \bullet)$, and peroxynitrite $\left(\mathrm{ONOO}^{-}\right)$, contributing to the compound stability.

Mechanisms of antioxidant activities may include (1) suppression of ROS formation either through enzyme inhibition or by binding of elements involved in the production of free radicals; (2) removal of ROS; and (3) direct improvement or protection by antioxidant compounds (Halliwell \& Gutteridge, 1998; Mishra et al. 2013). Flavonoid activity involves most of the mechanisms mentioned before. Several effects are mediated by the combined result of eliminating radical activity and interactions with enzyme function. Flavonoids inhibit enzymes involved in the generation of ROS, namely, microsomal monooxygenase, glutathione, S-transferase, mitochondrial succinate oxidase and NADH oxidase (Brown et al. 1998).

Lipid peroxidation is a common consequence of oxidative stress. Flavonoids protect lipids against oxidative damage through various mechanisms (Kumar et al. 2013; Kumar \& Pandey, 2012). Free metal ions increased the formation of ROS by reducing hydrogen peroxide with the production of a highly reactive hydroxyl radical. Due to the lower redox potential of thermodynamically flavonoids (Fl-OH), the compounds are able to reduce the oxidation of free radicals in the range between 2.13$1.0 \mathrm{~V}$, i.e superoxides, peroxyls, alkoxyls, and hydroxyl radicals by the donation of hydrogen atoms. Flavonoids are also able to bind metal ions ( $\mathrm{Fe}, \mathrm{Cu}$, etc.) and inhibit free radicals (Mishra et al. 2013; Mishra et al. 2013). Quercetin, an example of flavonoid, is known to bind iron and stabilize iron components. The metal binds to a specific position of the ring that is different from the flavonoid structure (Van et al. 1996). 


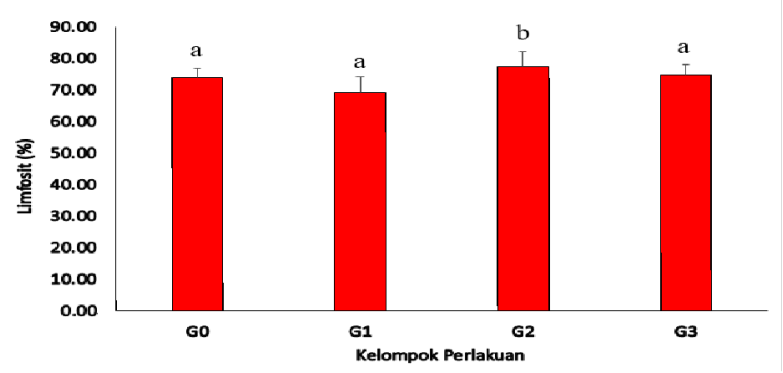

Fig 2. Effect of ethanolic leaf extract of $S$. vulcani to the lymphocyte count in rats

A high lymphocyte count may indicate a healthy state of an immune system. According to Talmale et al., (2014), flavonoids can trigger and stimulate macrophages for phagocytosis. Jioa et al., (1999) reported that flavonoid compounds stimulated lymphocyte proliferation by increasing the number of T cells and IL-2 activity in mice. Gabhe et al., (2006), also reported that the immunomodulatory activity is observed through the stimulation of lymphocyte proliferation which produced cytokines which activated other immune cells such as B cells, antigen-presenting cells (APC) and other $\mathrm{T}$ cells. Studies on lymphocyte transformation and direct cytokine assay clearly demonstrated the mechanism of immunostimulating activity because the general function of lymphocytes and other components of the immune system is to detect, identify and eliminate potential threatsin the body.Hematocrit is the volumetric proportion of erithrocytes and hemoglobins (Suharsono et al., 2010)

\subsection{Effect of ethanolic leaf extract of S. vulcani to interleukin-2}

Based on the statistical analysis, there was a significant difference in the results for $\mathrm{G}_{1}$, $(348.05 \pm 482.29 \mathrm{pg} / \mathrm{mL})$ which was the highest among other treatments. The lowest IL2 level was detected from $\mathrm{G}_{2}(67.8591 \pm 39.78 \mathrm{pg} / \mathrm{mL})$. Furthermore, the IL-2 level in $\mathrm{G}_{0}$ was $135.15 \pm 84.87 \mathrm{pg} / \mathrm{mL}$ while $\mathrm{G}_{3}$ was $106.7250 \pm 20.38 \mathrm{pg} / \mathrm{mL}$ (Figure 3). IL-2 levels in $\mathrm{G}_{1}$ are higher due to the presence of antigen from the sheep red blood cells (SRBC). The presence of a pro-inflammatory antigen such as IL-2 has the ability to stimulate various growth and cell activities. This is consistent with the statement of Subowo (2009), that IL-2 increases the activity of Th and Tc cells to overcome the antigens which enter the body.

The main function of the lymphocytes of the innate immune system is to provide an immediate response to viral infections. Apart from this function, natural killer cells (NK) can also differentiate between cancerous cells infected by microbes. NK cells target and destroy these cells in the same way while eliminating cells with viral infection. Although the site and process of NK cells maturation are not yet fully understood, billions are found circulating in human blood regularly. Miksusanti (2010) suggested the use of lymphocytes in immunological analysisdue to its moresusceptibility to chemicals which benefit for the detection.

In Figure 3, the IL-2 level was increased in $\mathrm{G}_{1}$ or SRBC treatment because IL-2 is a pro-inflammatory marker that increases when the antigen is present in the body. Sukmayadi et, al., (2014) stated that the increase in the mean number of IL-2 was due to the effect of the immodulatory activity of ethanol extract from tempuyung leaves in male rats at a dose of $1400 \mathrm{mg} / \mathrm{kg} \mathrm{BW}$. Administration of EES followed by SRBC in 
$\mathrm{G}_{3}$ resulted in a very significant decrease of IL-2 compared to G1 $(p<0.005)$. However, the reduction was not significantly different from the control, $\mathrm{G}_{0}$ and $\mathrm{G}_{2}$ (Figure 3). This may due to the flavonoid content in the extract which possess antiinflammatory properties. In other study, plant extract with flavonoid compounds exhibit anti-inflammatory activity in rats at a dose of $180 \mathrm{mg} / \mathrm{kg} \mathrm{BW}$. Furthermore, Alam et al., (2015) reported that hexane extract from the sapwood of Aquilaria agallocha was known to exhibit anti-inflammatory activity induced by carrageenan at a dose of $100 \mathrm{mg} / \mathrm{kg} \mathrm{BW}$ which reduced the percentage of leg edema at $61.11 \%$ in rats.

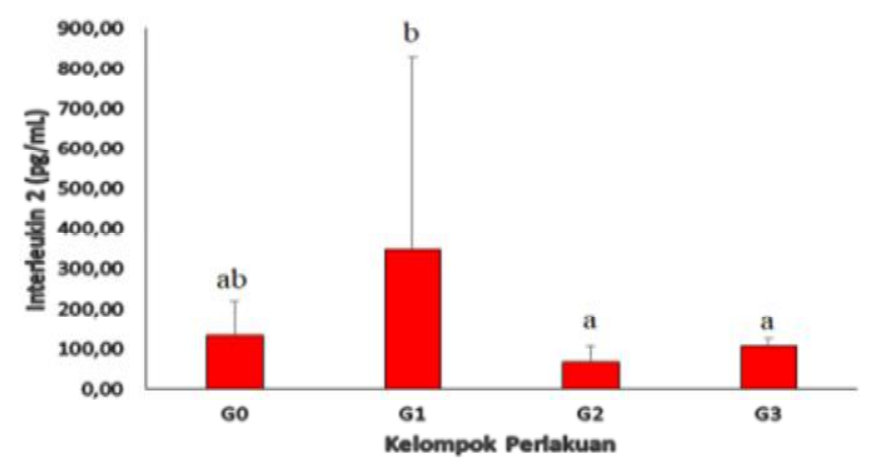

Fig 2. Effect of ethanolic leaf extract of S. vulcani to the IL-2 level in rats Antibody secretion is greatly decreased in the absence of helper T cells. Helper T cells secrete $\mathrm{T}$ cell growth factor, known as interleukin 2 (IL-2) to increase the activity of cytotoxic $\mathrm{T}$ cells, suppressor $\mathrm{T}$ cells, and even other helper $\mathrm{T}$ cells that are responsive to incoming antigens (Subowo, 2009). Biron et al., (2013), also reported from their laboratory study using mice as experimental animals, revealed that IL-2 induced the NK cells proliferation and activiated $\mathrm{T}$ cells.

\section{REFERENCES}

[1] Abbas, A.K. Licthman, A.H. dan Pilai, S. 2007. Cells and Tissues of the Adaptive Immune System. Celluler and Molleculler Immunology 6th. Ed.Philadelphia, Wb saunders.

[2] Alam J, Mujahid M, Badruddeen, Rahman MA, Akhtar J, Khalid M,. 2015. An insight of pharmacognostic study and phytopharmacology of Aquilariaagallocha. Journal of Applied Pharmaceutial Science, 5(08), 173-181

[3] AkromdanSiti. 2007. JumlahdanAktifitasProliferase Lien Mencit Swiss Jantan Yang Diinfeksi Plasmodium Berghei Akibat Pemberian 5 dan $100 \mathrm{mg} / \mathrm{kg} \mathrm{BB} /$ hari Ekstrak Etanol Phylanthusniruri. J. Kes.Mes. vol 1(1) : 1-50

[4] Biron C. A, H A Young, M T Kasaian. 1990. Interleukin 2- Induced Proliferatation Of Murine Natural Killer Cells In Vivo. Journal of Experimental Medicine. DOI : $10.1084 / \mathrm{jem} .171 .173$

[5] Kumar V., Cotran R. S., Robbins S. L.(eds). Buku Ajar Patologi Robbins. Volume 2. Edisi VII. Jakarta: EGC, pp: 572. 594-7

[6] Francis G, Kerem Z, Makkar HPS, Becker K. 2002. The Biological Action of Saponins in Animal Systems: a review. British J Nutri. 88 : 587-605.

[7] Govind, P, Madhuri S, dan K. A Mandloi. 2012. Immunostimulant Effect of Medicinal Plants on Fish. International Research Journal of Pharmacy. 3(3):112-114 
[8] Harborne, J.B. 1987. MetodeFitokimiaPenuntun Cara Modern MenganalisisTumbuhan, Cetakan II, Diterjemahkanoleh K, Padinawinatadan I, Soediro. Bandung: Penerbit ITB.

[9] Kumar IJ, Chelladurai G, VeniT ,Peeran SSH , Mohanraj J. 2014. Medicinal plants as immunostimulants for health management in Indian cat fish. Journal of Coastal Life Medicine. 2(6): 426-430.

[10] Kumar, S., Gupta, P., Sharma, S., Kumar, D. 2011. A Review on Immunostimulatory Plants. Journal of Chinese Integrative Medicine. Vol 9 (2). 117-128.

[11] Rajput ZI, Hu SH, Xiao CW, Arijo AG. 2007. Adjuvant effects of saponins on. Animal immune responss. J Zhejiang UnivSci B. 8(3): 153-61.

[12] Sitorus, 2015. Simplisia Characterisation and extract Ethanol of Pirdotleaves (Saurauiavulcani Korth) and Effect Of Study Anti diabetic In Induced Rats (Rattusnorvegicus). International Journal of Chemichal Technology Research. Vol. 8, No. 6, pp 789-794.

[13] Subowo, 2009. Immunobiology. UI Press

[14] Sundaryono, A. 2011. Uji Aktvitas Senyawa Flavonoid Total dari Gynurasegetum (Lour) terhadap Peningkatkan Eritrosit dan Penurunan Leukosit Pada Mencit (Mus musculus). Jurnal Excata : 9 (2) :8-16

[15] Talmale Bhujade., Patil.2014.Immunostimulatory Activity Of Flavonoids Isolated From Stem Bark Of Zizyphus Mauritiani. Internasional Journal of Innovative Research in Science, Enginering and Technologys: 14285-14296

[16] Teiceira, D. Longo-Mauregi, CM. Duarte, Yao, Lebrao, ML, dan V. Bueno. 2013. Evaluation of Renal Function and Immune System Cells in Eldery Individual From Sao Paula City. Clinics. $39-44$

[17] Tizard IR. 2004. Veterinary Immunology an Introduction. Edisi ke-7: Saunders.

[18] Trask BC, Rote NS, Huether SE. Immate Immunity: Inflammation. Dalam: McCance KL, Huether SE, editor. Pathophysiology: The Biologic Basic for Disease in Adults and Children. Edisi ke-5. Missouri: Elsevier Mosby; 2006. H. 175-209.

[19] Tumangger,H., Anas S., Supriyatna. (1999). Penapisan Efek Anti Depresi dan Fitokimia Beberapa Tumbuhan Pakan Primata dengan Metode Berenang. Cermin Dunia Kedokteran 123:28-34. 